J Urol Nephrol

January 2017 Vol.:4, Issue:1

() All rights are reserved by Maria,et al.

\title{
Cocaine Intoxication: A Rare Cause of Thrombotic Microangiopathy
}

Keywords: Cocaine; Thrombotic microangiopathy; Hemolytic: Uremic syndrome

\begin{abstract}
Cocaine abuse and intoxication is a global problem leading to many medical complications that can result in significant morbidity and mortality. Many lesions, including thrombotic microangiopathy, can cause acute renal injury associated with cocaine use. We report the case of a patient who developed thrombotic microangiopathy in the context of cocaine intoxication. A 40-year-old man, with a history of intermittent cocaine abuse, was transferred to the Department of Nephrology at Aristide Le Dantec University Hospital in Dakar, for the management of declining renal function in the context of acute agitation. Physical examination showed a blood pressure of $160 / 100$ $\mathrm{mmHg}$, and proteinuria and haematuria each at three crosses in a dipstick urinary test. Neurological examination found psychometric agitation without localization. Cardiac, pulmonary, abdominal, musculoskeletal and lymph node examinations were normal. Biological investigations on admission revealed:mechanical haemolyticanaemia thrombocytopenia and serum creatinine at $3.8 \mathrm{mg} / \mathrm{dll}$, blood urea at $182 \mathrm{mg} / \mathrm{dl}$. The renal ultrasound showed normal kidney size but bad differentiation. Kidney biopsy was performed and showed partial collapse of the tuft in ten glomeruli, three of which contained fibrin thrombi with sub-occlusive mucoidendothelitis and fibrinoid necrosis of arterioles. The diagnosis of thrombotic microangiopathy revealed by a haemolytic and uraemic syndrome in a cocaine intoxication context was confirmed. Evolution was favourable after blood pressure control using combined amlodipine and ramipril at full dose, and the transfusion of three units of red blood cellsand fresh frozen plasma. The patient is currently being monitored as a nephrology outpatient. At his last check up, he had a good general condition and his GFR was 29 $\mathrm{ml} / \mathrm{min} / 1.73 \mathrm{~m} 3$.
\end{abstract}

\section{Introduction}

Cocaine abuse and intoxication is a global problem leading to many medical complications that can result in significant morbidity and mortality [1]. Current users of cocaine in the United States over the age of 12 years numbered 1.5 million in 2010, while 4 million Europeans aged 15 to 64 used cocaine in 2009 [2]. There are no equivalent data from Africa. Cocaine abuse and intoxication is most common in young adults [1]. Cocaine abusers may present for medical care with manifestations related to the acute sympathomimetic effects of cocaine or with manifestations related to complications resulting from cocaine use [1]. Many lesions, including thrombotic microangiopathy, can cause acute renal injury associated with cocaine use [3]. We report the case of a patient who developed thrombotic microangiopathies (TMAs) in the context of cocaine intoxication.

\section{Case Report}

A 40-year-old man with a history of intermittent cocaine abuse, alcohol and tobacco dependence was transferred to the Department of Nephrology at Aristide Le Dantec University Hospital in Dakar, for the management of declining renal function in the context of acute

\section{Journal of}

Urology \& Nephrology

Lemrabott Ahmed Tall ${ }^{1}$, Faye Maria ${ }^{*}$, Kane Yaya ${ }^{2}$, Fall Kodia', Nzambaza Jean-De-Dieu', Ba Bakary', El Hadji Fary Ka ${ }^{1}$, Niang Abdou ${ }^{1}$ and Diouf Boucar ${ }^{1}$

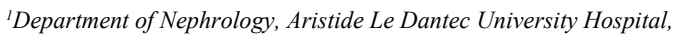
Dakar, Senegal

${ }^{2}$ Nephrology and Internal Medicine Department of Assane Seck University, Ziguinchor, Senegal

Address for Correspondence

Faye Maria, Department of Nephrology, Aristide Le Dantec University Hospital, 30, Avenue Pasteur, BP: 3001, Dakar, Senegal, Tel: 00221776576776; E-mail: mariafye@hotmail.com

Submission: 28 October, 2016

Accepted: 23 December, 2016

Published: 06 January, 2017

Copyright: (c) 2017 Faye M, et al. This is an open access article distributed under the Creative Commons Attribution License, which permits unrestricted use, distribution, and reproduction in any medium, provided the original work is properly cited.

agitation. At baseline, he was highly functioning with no psychiatric history. In the emergency department, he was able to follow commands, but had slurred speech, uncoordinated movements, and fluctuating agitation that required temporary restraints. His only complaint was vomiting for the last 3 days. The patient revealed that he had used cocaine 4 days prior to admission.

Physical examination revealed a temperature of $37.3^{\circ} \mathrm{C}$, blood pressure of $160 / 100 \mathrm{mmHg}$, respiratory rate of 17 breaths $/ \mathrm{min}$, and a pulse rate of 92 beats/min. Neurological examination found psychometric agitation without localization. Cardiac, pulmonary, abdominal, musculoskeletal and lymph node examinations were normal. In a dipstick urinary test, both proteinuria and haematuria were recorded as three crosses.

Biological investigations on admission revealed: mechanical haemolyticanaemia with haemoglobin at $7.3 \mathrm{~g} / \mathrm{dl}$ and schizocytes in the peripheral blood smear at $2 \%$, thrombocytopenia $72,000 / \mathrm{mm}^{3}$, leukocytosis at $11,580 / \mathrm{mm}^{3}$, negative Coombs test, serum creatinine at $3.8 \mathrm{mg} / \mathrm{dl}$, blood urea at $182 \mathrm{mg} / \mathrm{dl}$, serum corrected calcium at $8.4 \mathrm{mg} / \mathrm{dl}$ and hyperphosphatemia at $6.2 \mathrm{mg} / \mathrm{dl}$. In blood electrolytes, sodium was $127 \mathrm{mmol} / \mathrm{l}$, potassium $3.4 \mathrm{mmol} / \mathrm{l}$. Transaminases were raised, with serum glutamic-oxaloacetic transaminase (SGOT) at $110 \mathrm{IU} / \mathrm{l}$ and serum glutamic-pyruvic transaminase (SGPT) at 180 UI/l. Blood sugar was $90 \mathrm{~g} / \mathrm{dl}$. C-reactive protein (CRP) was $9.6 \mathrm{mg} /$ $\mathrm{dl}$ (Table 1). Urinalysis revealed proteinuria at $1.2 \mathrm{~g} / 24 \mathrm{~h}$ and a toxicology screen was positive for cocaine.

On the third day after his admission, serum creatinine was at $12 \mathrm{mg} / \mathrm{dl}$. The renal ultrasound showed normal kidney size but bad differentiation.

Kidney biopsy was performed after normalization of blood pressure, anaemia and thrombocytopenia. Seventeen glomeruli were present in the biopsy specimen. Six glomeruli were sclerosed, 58\% 
Citation: Tall LA, Maria F, Yaya K, Kodia F, Jean-De-Dieu N, et al. Cocaine Intoxication: A Rare Cause of Thrombotic Microangiopathy. J Urol Nephrol. 2017;4(1): 3

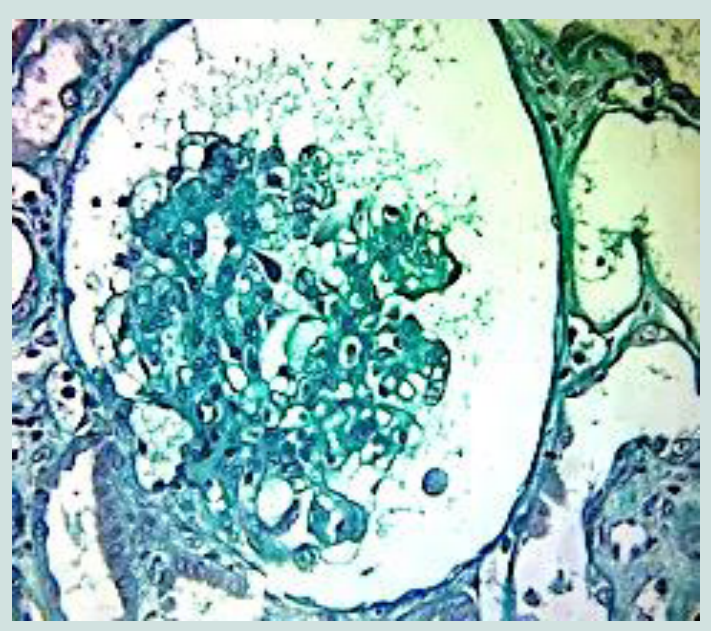

Figure 1: Glomerulus with Partial Collapse Masson's. Trichrome Stain x 250. Gros x 250 .

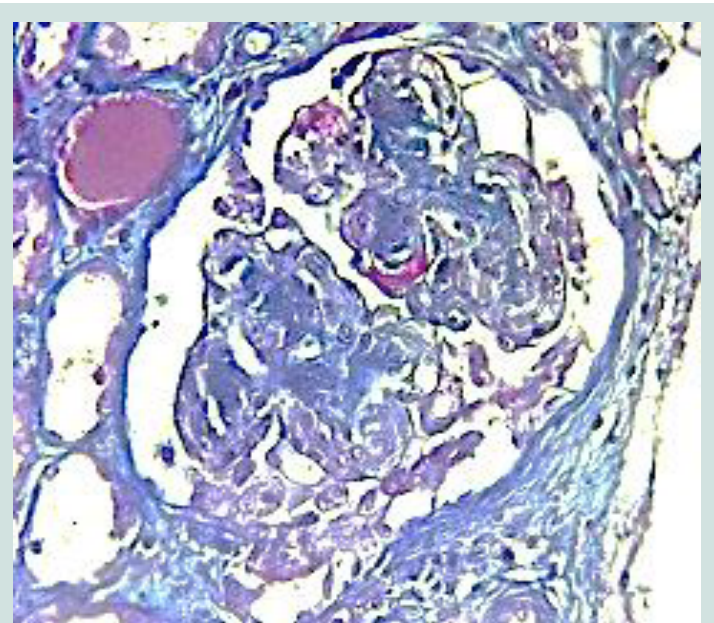

Figure 2: Fibrin Thrombi in Glomerulus. Masson's. Trichrome Stain $\times 250$.

(10/17) of glomeruli showed partial collapse of the tuft (Figure 1), and three of these contained fibrin thrombi (Figure 2). There was also acute tubular injury involving both proximal and distal convoluted tubules. Interlobular arteries showed subocclusive mucoid endothelitis and fibrinoid necrosis of arterioles, which are features of thrombotic microangiopathy (Figure 3).

The diagnosis of thrombotic microangiopathy (TMA) revealed by a haemolytic and uraemic syndrome (HUS) in the context of cocaine intoxication was confirmed. Evolution was favourable after blood pressure control using combined amlodipine and ramipril at full dose, and fresh frozen plasma transfusion. The patient is currently being monitored as a nephrology outpatient. At his last check up, he was in good general health and his GFR was $29 \mathrm{ml} / \mathrm{min} / 1.73 \mathrm{~m}^{2}$.

\section{Discussion}

The pathophysiological basis of cocaine-related renal injury is multifactorial and involves one or a combination of changes in renal haemodynamics, changes in glomerular matrix synthesis, degradation, and oxidative stress and induction of renal atherogenesis [3]. Acute renal failure can also occur in patients with acute cocaine intoxication and it is well known that the most common kidney complication is rhabdomyolysis [4]. Reported cocaine-associated thrombotic microangiopathy is rare with few reported cases in the literature. In 1990 Tumlin reported the first case of TMAs after cocaine abuse [5] (Table 2). Our patient is a 40-year-old man. The majority of cases in the literature were women (4/7) aged between 26 to 56 years (Table 2).

Our patient presented with agitation as in the major case reports of cocaine intoxication (Table 2). Acute agitation is the most common

Table1: Epidemiological, clinical and biological parameters of the patient.

\begin{tabular}{|c|c|}
\hline Parameters & Results \\
\hline $\begin{array}{c}\text { Epidemiological parameters } \\
\text { Age } \\
\text { Gender } \\
\text { profession }\end{array}$ & $\begin{array}{l}40 \text { years } \\
\text { male } \\
\text { no wocker }\end{array}$ \\
\hline $\begin{array}{l}\text { Clinical parameters } \\
\text { Blood pressure } \\
\text { Temperature } \\
\text { Respiratory pulse } \\
\text { Cardiac pulse } \\
\text { Dipstick urinary test } \\
\text { Proteinuria } \\
\text { Heamaturia }\end{array}$ & $\begin{array}{c}160 / 100 \mathrm{mmHg} \\
37.3^{\circ} \mathrm{C} \\
17 / \mathrm{min} \\
92 \text { beats } / \mathrm{min} \\
3 \text { crosses } \\
3 \text { crosses }\end{array}$ \\
\hline $\begin{array}{c}\text { Biological parameters } \\
\text { Hemoglobin } \\
\text { Leukocytosis } \\
\text { Platelets } \\
\text { Schizocytes } \\
\text { Serum creatinine } \\
\text { Serum Urea } \\
\text { Calcemia } \\
\text { Phosphatemia } \\
\text { Blood sodium } \\
\text { Blood potassium } \\
\text { SGOT } \\
\text { SGPT } \\
\text { CRP } \\
\text { Proteinuria } \\
\text { Urine toxicology screen }\end{array}$ & $\begin{array}{c}7.3 \mathrm{~g} / \mathrm{dl} \\
11.580 / \mathrm{mm}^{3} \\
72.000 / \mathrm{mm}^{3} \\
2 \% \\
3.8 \mathrm{mg} / \mathrm{dl} \\
182 \mathrm{mg} / \mathrm{dl} \\
8.4 \mathrm{mg} / \mathrm{dl} \\
6.2 \mathrm{mg} / \mathrm{dl} \\
127 \mathrm{mmol} / \mathrm{l} \\
3.4 \mathrm{mmol} / \mathrm{l} \\
110 \mathrm{IU} / \mathrm{l} \\
180 \mathrm{Ul} / \mathrm{l} \\
9.6 \mathrm{mg} / \mathrm{dl} \\
1.2 \mathrm{~g} / 24 \mathrm{~h} \\
\text { Positive for cocaine }\end{array}$ \\
\hline
\end{tabular}

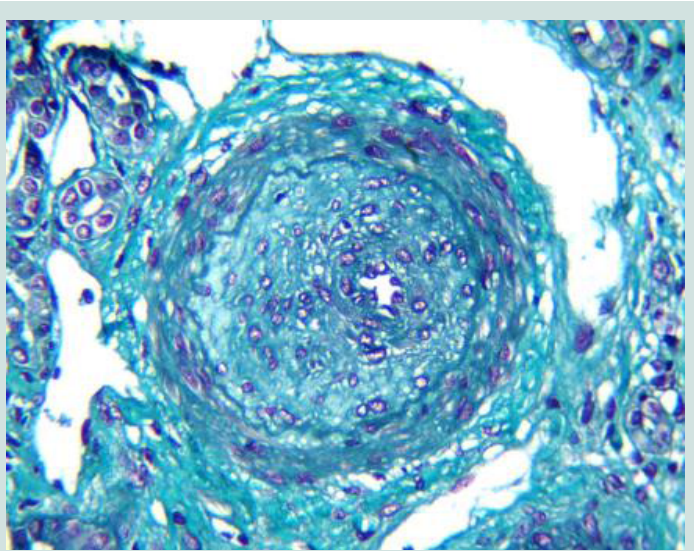

Figure 3: Artery with Sub Occlusive Mucoid endothelitis and Fibrinoid necrosis. Masson's Trichrome Stain x 300 . 
Citation: Tall LA, Maria F, Yaya K, Kodia F, Jean-De-Dieu N, et al. Cocaine Intoxication: A Rare Cause of Thrombotic Microangiopathy. J Urol Nephrol. 2017;4(1): 3 .

ISSN: 2380-0585

Table 2: Published cases to-date and the current study of cocaine-induced TMAs.

\begin{tabular}{|c|c|c|c|c|c|}
\hline Authors & Year & Age/ gender & Presentation & Diagnosis & Treatment \\
\hline Tumlin JA [5] & 1990 & 28/Female & $\begin{array}{l}\text { Mental confusion, Diffuse } \\
\text { abdominal pain }\end{array}$ & Cocaine induced HUS & Dialysis \\
\hline Keung YK [10] & 1996 & 56/Male & Mental confusion & Cocaine induce MAHA & Spontaneous recovery \\
\hline Volcy J [11] & 2000 & 38/Female & Weakness, epistaxis, dizziness & TTP & $\begin{array}{l}\text { Dialysis, Fresh frozen } \\
\text { plasma transfusion }\end{array}$ \\
\hline Balaguer F [12] & 2005 & 22/Female & Weakness, vomiting, fever & Cocaine induced TMA & Plasma exchange \\
\hline Odronic S [13] & 2014 & 53/Female & Mental confusion & Cocaine induce MAHA & Plasma exchange \\
\hline Rais L [6] & 2016 & 26/Male & $\begin{array}{l}\text { Malignant } \\
\text { hypertension }\end{array}$ & $\begin{array}{l}\text { Malignant hypertension } \\
\text { associated TMA following } \\
\text { cocaine use }\end{array}$ & Dialysis \\
\hline Current study & 2016 & 40/Male & Mental confusion & TMAs & $\begin{array}{l}\text { Fresh frozen plasma } \\
\text { transfusion }\end{array}$ \\
\hline
\end{tabular}

presentation of cocaine intoxication in hospitals. The central nervous system effects of intoxication are most likely due to excess dopaminergic activity that produces profound euphoria and selfconfidence at lower doses and agitation and delirium at higher doses. Immediate intervention is often necessary to prevent self-injury or worsening of cocaine-related complications [1]. Hypertension was present in our patient. Cocaine abuse is usually associated with high blood pressure. The resulting vasoconstrictive effect of cocaine is primarily due to the stimulation of alpha-adrenergic receptors in arterial smooth muscle cells. Increased endothelin-1 and decreased nitric oxide blood concentrations may also contribute to cocaine's vasoconstrictive properties [1]. Rais reported malignant hypertension-associated thrombotic microangiopathy following cocaine use [6]. The clinical findings were more consistent with thrombotic thrombocytopenic purpura (TTP) than HUS (Table 2). The clinical presentation in our case was an HUS like the first case of cocaine-induced TMAs reported by Tumlin [5].

Previous kidney biopsies revealed typical features of thrombotic microangiopathy with fibrinoid necrosis of arterioles and glomeruli, vascular sclerosis and glomerulosclerosis $[7,8]$. In our case the kidney biopsy revealed partial collapse of the tuft in $58 \%$ of glomeruli, and some of these contained fibrin thrombi, and fibrinoid necrosis in small interlobular arterioles. Damage to the endothelium and activation of platelets further triggered thrombosis and fibrinoid necrosis in small vessels and capillaries and resulted in the morphological changes characteristic of thrombotic microangiopathy [7,9-13] Several regions of tubular necrosis in our patient could be attributed to vasoconstriction and the traditional medicine used by the patient before coming to hospital. Evolution was favourable after blood pressure control using combined amlodipine and ramipril at full dose, and fresh frozen plasma transfusion. Most of the previous case reports had a favorable evolution but treatment was different (Table 2).

\section{Conclusion}

This case report is illustrative of the gravity of cocaine intoxication. TMAs are a possible renal complication. Clinicians need to have a high level of suspicion for possible cocaine-induced TMA in cocaine users who present similar to patients with HUS. Evolution should be favourable through prompt management. However, prevention of cocaine use is the main treatment.

\section{References}

1. Zimmerman JL (2012) Cocaine intoxication. Crit Care Clin 28: 517-526.

2. SAMHSA (Substance Abuse and Mental Health Services Administration) (2011) Results from the 2010 National Survey on Drug Use and Health: Summary of National Findings.

3. Nzerue CM, Hewan-Lowe K, Riley LJ Jr (2000) Cocaine and the kidney: a synthesis of pathophysiologic and clinical perspectives. Am J Kidney Dis 35: 783-795.

4. Van der Woude FJ (2000) Cocaine use and kidney damage. Nephrol Dial Transplant 15: 299-301.

5. Tumlin JA, Sands JM, Someren A (1990) Hemolytic-uremic syndrome following "crack" cocaine inhalation. Am J Med Sci 299: 366-371.

6. Lamia R, El Ati Z, Ben Fatma L, Zouaghi K, Smaoui W et al. (2016) Malignant hypertension-associated thrombotic microangiopathy following cocaine use. Saudi J Kidney Dis Transpl 27: 153-156.

7. Jeffcoat AR, Perez-Reyes M, Hill JM, Sadler BM, Cook CE (1989) Cocaine disposition in humans after intravenous injection, nasal insufflation (snorting), or smoking. Drug Metab Dispos 17: 153-159.

8. Lange RA, Hillis LD (2001) Cardiovascular complications of cocaine use. $\mathrm{N}$ Engl J Med 345: 351-358.

9. Togna G, Tempesta E, Togna AR, Dolci N, Cebo B, et al. (1985) Platelet responsiveness and biosynthesis of thromboxane and prostacyclin in response to in vitro cocaine treatment. Haemostasis 15:100-107.

10. Keung YK, Morgan D, Cobos E (1996) Cocaine-induced microangiopathic hemolytic anemia and thrombocytopenia simulating thrombotic thrombocytopenia purpura. Ann Hematol 72: 155-156.

11. Volcy J, Nzerue CM, Oderinde A, Hewan-lowe K (2000) Cocaine- induced acute renal failure, hemolysis, and thrombocytopenia mimicking thrombotic thrombocytopenic purpura. Am J Kidney Dis 35: E3.

12. Balaguer F, Fernandez J, Lozano M, Miquel R, Mas A (2005) Cocaineinduced acute hepatitis and thrombotic microangiopathy. JAMA 293: 797798.

13. Odronic S, Quraishy N, Manroa P, Kier Y, Koo A et al. (2014) Cocaineinduced microangiopathic hemolytic anemia mimicking idiopathic thrombotic thrombocytopenic purpura: a case report and review of the literature. $\mathrm{J}$ Clin Apher 29: 284-289.

\section{Acknowledgements}

We would like to thank the International Society of Nephrology (ISN). 